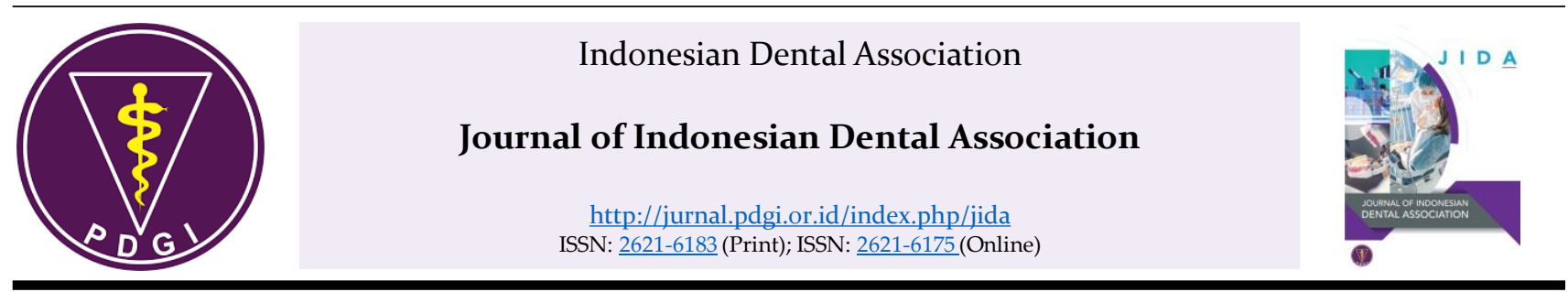

Research Article

\title{
Jigsaw versus Conventional Method towards Children's Attitude and Knowledge of Dental and Oral Health
}

\author{
Likky Tiara Alphianti's, Ariska Mei $^{2}$ \\ ${ }^{1}$ School of Dentistry, Faculty of Medicine and Health Sciences, Muhammadiyah of Yogyakarta University, Indonesia \\ ${ }^{2}$ Undergraduate Student, School of Dentistry, Faculty of Medicine and Health Sciences, Muhammadiyah of Yogyakarta University, \\ Indonesia
}

Received date: August 8, 2019. Accepted date: October 7, 2019. Published date: October 31, 2019

\author{
KEYWORDS \\ attitude; \\ conventional learning method; \\ jigsaw cooperative learning \\ method; \\ knowledge
}

\begin{abstract}
Introduction: The effort in improving dental and oral health could be taken by giving information about oral and dental health as early as possible. Jigsaw cooperative learning method and conventional learning method are two of several learning methods that commonly used in order to giving information about dental and oral health. Objectives: The purpose of this study was to determine the comparison between both learning methods between, jigsaw cooperative and conventional, towards children's attitude and knowledge of dental and oral health. Methods: This study was a quasi-experimental with non-randomized control group pretest and post-test design. Sixty-eight students aged 10-11 from Muhammadiyah Suronatan Yogyakarta Elementary School was taken as the subjects and divided into 2 groups. Group A $(n=36)$ was jigsaw cooperative learning method group and group $B(n=32)$ was conventional learning method group. Each subject fulfilled two types questionnaire before and after giving lecture, such as attitude's questionnaire and knowledge's questionnaire of dental and oral health. Data were analyzed using paired t-test and independent t-test. Results: From the result of paired t-test, it showed that there were significant differences between before and after treatment in both groups at knowledge aspect (Group A: $\mathrm{p}=0.000$ and group $\mathrm{B}: \mathrm{p}=0.015$ ) as well as attitude aspect (group $\mathrm{A}$ and $\mathrm{B} ; \mathrm{p}=0.000$ respectively). Independent $\mathrm{t}$-test showed there were significant differences between both groups in knowledge $(\mathrm{p}=0.003)$ and attitude $(\mathrm{p}=0.000)$. Conclusion: In this study, there were significant difference between jigsaw cooperative learning method and conventional learning method at knowledge and attitude aspects in children aged 10-11 years old. Children in group jigsaw cooperative learning method have higher score than children in group conventional learning method.
\end{abstract}

\footnotetext{
$\S$ Corresponding Author

E-mail address: drg.likky@gmail.com (Alphianti LT)
}

\section{DOI: $10.32793 /$ jida.v2i2.399}

Copyright: (C2019 Alphianti LT, Mei A. This is an open access article distributed under the terms of the Creative Commons Attribution License, which permits unrestricted use, distribution, and reproduction in any medium provided the original author and sources are credited. 


\section{KATA KUNCI}

metode pembelajaran konvensional; metode pembelajaran kooperatif tipe jigsaw; pengetahuan; sikap

\begin{abstract}
ABSTRAK
Pendahuluan: Upaya untuk meningkatkan kesehatan gigi dan mulut melalui penyampaian informasi kesehatan gigi dan mulut sejak dini. Metode pembelajaran untuk memberikan informasi mengenai kesehatan gigi dan mulut antara lain metode kooperatif jigsaw dan metode konvensional. Tujuan: Penelitian ini dilakukan untuk membandingkan antara dua metode pembelajaran, yaitu metode kooperatif jigsaw dengan metode konvensional terhadap pembentukan sikap dan pengetahuan kesehatan gigi dan mulut pada anak. Metode: Rancangan penelitian ini adalah Eksperimental Kuasi dengan Non Randomized Control Group Pre-Test dan Post-Test Design. Subjek penelitian ini adalah 68 siswa SD Muhammadiyah Suronatan Kota Yogyakarta usia 10-11 tahun; 36 siswa sebagai kelompok perlakuan (A) yaitu pembelajaran kooperatif jigsaw dan 32 siswa sebagai kelompok kontrol (B) yaitu pembelajaran konvensional. Setiap subjek mengisi dua jenis kuisioner yaitu: kuisioner sikap dan kuisioner pengetahuan kesehatan gigi dan mulut sebanyak dua kali saat sebelum dan sesudah dilakukan perlakuan/pembelajaran,. Paired t-test dan independent sample t-test digunakan untuk analisis data penelitian. Hasil: Berdasarkan uji paired t-test menunjukkan terdapat perbedaan signifikan antara sebelum dan sesudah pemberian perlakuan pada kedua kelompok, baik pada aspek pengetahuan (Kelompok $\mathrm{A}: \mathrm{p}=0,000$ dan kelompok $\mathrm{B}: \mathrm{p}=0,015$ ) dan pada aspek sikap (kelompok A dan B: $\mathrm{p}=0,000$ ). Hasil independent sample t-test menunjukkan terdapat perbedaan signifikan antara kedua metode pembelajaran pada aspek pengetahuan $(p=0,003)$ dan aspek sikap $(\mathrm{p}=0,000)$. Kesimpulan: Pada penelitian ini dapat disimpulkan terdapat perbedaan signifikan terhadap sikap dan pengetahuan tentang kesehatan gigi dan mulut antara metode kooperatif jigsaw dengan metode konvensional pada anak usia 10-11 tahun di SD Muhammadiyah Suronatan Yogyakarta. Anak pada kelompok metode kooperatif jigsaw memiliki nilai lebih tinggi dibandingkan metode konvensional.
\end{abstract}

\section{PENDAHULUAN}

Kesehatan gigi dan mulut oleh masyarakat sering kali tidak dihiraukan, sementara itu telah diketahui bahwa gigi dan mulut merupakan pintu masuk bagi mikroorganisme yang dapat mengganggu organ tubuh lainnya. ${ }^{1}$ Rongga mulut memiliki peranan yang penting dalam kehidupan dengan berbagai macam fungsinya seperti mastikasi, estetik, fonetik, komunikasi dan ekspresi emosi. ${ }^{2}$ World Health Organization (WHO) dalam The World Oral Health Report melaporkan bahwa kurangnya menjaga kesehatan gigi dan mulut di Indonesia menyebabkan peningkatan prevalensi kerusakan gigi sebanyak $24 \%$ dan penderita gangguan kesehatan gigi mencapai 90\%. Sejak tahun 2007 sampai 2013, telah dilaporkan pula terjadi peningkatan penderita karies aktif dengan peningkatan terbesar pada usia 12 tahun $(13,7 \%)$ dan di atas 65 tahun $(14,3 \%))^{3}$ Upaya untuk meningkatkan kesehatan gigi dan mulut antara lain dengan memberikan penyuluhan mengenai kesehatan gigi dan mulut sejak usia dini. Anak usia sekolah yang sudah diajari tentang pengetahuan kesehatan gigi dan mulut serta cara untuk memelihara kebersihan gigi dan mulut, maka akan mempunyai pengetahuan yang optimal dan keterampilan yang memadai serta kemauan dalam memelihara kesehatan gigi dan mulut. ${ }^{2}$

Kesehatan gigi dan mulut memiliki hubungan dengan pengetahuan, sikap dan perilaku ${ }^{4}$. Sikap adalah perasaan mendukung maupun perasaan yang tidak mendukung pada suatu obyek. Sikap manusia dapat dipengaruhi oleh faktor luar. Faktor tersebut adalah faktor dari luar individu yang dengan sengaja diberikan sehingga individu yang bersangkutan akan menerapkan sikap-sikap tertentu, baik disadari maupun tidak disadari. $^{5}$

Pengetahuan dan pendidikan berhubungan sangat erat, sehingga semakin tinggi pendidikan seseorang maka diharapkan akan semakin luas pula tingkat pengetahuannya. Faktor perilaku atau sikap yang mengacuhkan kebersihan gigi dan mulut merupakan salah satu penyebab munculnya masalah pada kesehatan gigi dan mulut di masyarakat. Hal tersebut dipicu oleh rendahnya pengetahuan akan pentingnya pemeliharaan gigi dan mulut. ${ }^{6}$

Metode pembelajaran adalah jenis pembelajaran yang dilaksanakan oleh guru dalam menerapkan suatu sistem secara spesifik. ${ }^{7}$ Metode pembelajaran antara lain: ceramah, tanya jawab, diskusi, demonstrasi, sosiodrama, bermain peran, simulasi, tanya jawab, proyek problem solving, kooperatif, inkuiri-discovery dan karya wisata. Salah satu metode pembelajaran kooperatif adalah tipe jigsaw. Siswa dibagi menjadi beberapa kelompok yang anggotanya mempunyai karaktersitik heterogen dalam pembelajaran tipe jigsaw. Tiap siswa bertugas untuk mengkaji tema yang diberikan kemudian memberitahukan pada anggota di kelompoknya, sehingga setiap siswa dalam kelompok tersebut saling berinteraksi dan berkolaborasi. ${ }^{8}$ 
Anak usia sekolah dasar (7-11 tahun), berada pada tahap operasional konkret. Anak pada usia 10-11 tahun sudah mampu mempraktekkan kelogisan berpikir untuk hal-hal yang bersifat konkret atau nyata, namun masih belum mampu untuk hal-hal yang bersifat abstrak. Anak dapat mengelompokkan obyek nyata ke dalam kelompok yang bervariasi. ${ }^{9}$

Merawat kesehatan gigi dan mulut sangat esensial namun terkadang metode pembelajaran yang diterapkan dalam memberikan materi tentang kesehatan gigi dan mulut terkadang kurang efektif. Berdasarkan latar belakang tersebut maka penulis ingin melakukan penelitian untuk membandingkan antara dua metode pembelajaran yaitu kooperatif jigsaw dan konvensional terhadap perbedaan sikap dan pengetahuan kesehatan gigi dan mulut.

\section{BAHAN DAN METODE}

Penelitian ini merupakan penelitian Eksperimental Kuasi dengan Non Randomized Control Group Pre-Test dan Post-Test Design. Pemilihan subyek pada penelitian ini adalah menggunakan teknik total sampling. Subyek yang digunakan dalam penelitian ini adalah seluruh siswa kelas V SD Muhammadiyah Suronatan Kota Yogyakarta usia 10 -11 tahun sejumlah 68 anak, kelas A berjumlah 36 siswa untuk kelompok perlakuan yaitu pembelajaran kooperatif tipe jigsaw dan kelas B berjumlah 32 siswa untuk kelompok kontrol yaitu pembelajaran konvensional. Penelitian dilaksanakan di SD Muhammadiyah Suronatan Kota Yogyakarta pada tanggal 3 April 2019. Setiap subyek mengisi dua jenis kuesioner (kuesioner sikap dan kuesioner pengetahuan), dan tiap kuisioner dikerjakan sebanyak 2 kali sebelum (pre test) dan sesudah (post test) dilakukan pembelajaran tentang kesehatan gigi dan mulut. Kuesioner sikap dan pengetahuan tentang kesehatan gigi dan mulut merupakan modifikasi kuisioner dari penelitian yang dilakukan oleh Arifah (2016) dan telah dilakukan uji validitas dan reabilitas.

Kuisioner sikap terdiri dari 18 pertanyaan mengenai sikap terhadap pemeliharaan kesehatan gigi dan mulut dengan pertanyaan sebagai berikut: 1 . Menyikat gigi minimal dua kali sehari; 2. Gigi berlubang disebabkan konsumsi gula yang berlebihan; 3. Gigi berlubang akan sembuh sendiri tanpa ditambal; 4 . Kontrol kesehatan gigi ke dokter gigi 6 bulan sekali; 5. Normalnya gusi memang mudah berdarah saat menyikat gigi; 6 . Menyikat gigi setiap hari sebelum tidur; 7. Jika belum timbul rasa sakit maka gigi tidak perlu diobati; 8 . Menyikat gigi dua kali saat mandi pagi dan sore; 9. Bertukar sikat gigi dengan teman/orang lain; 10. Merokok dapat mempengaruhi kesehatan gigi dan mulut; 11. Menyikat gigi di seluruh permukaan gigi; 12. Kekurangan vitamin dapat mempengaruhi kondisi gusi; 13. Gigi sehat adalah gigi yang kuat dan tidak berlubang; 14. Kesehatan gigi dan mulut mempengaruhi kondisi kesehatan secara umum; 15. Gigi dicabut saat sakit; 16. Menyikat gigi bagian depan saja, karena gigi tersebut sering dilihat; 17. Gigi goyang sebaiknya dicabut; 18. Jika belum timbul rasa sakit maka gigi tidak perlu diobati. Pengukuran sikap menggunakan perhitungan skala Likert untuk pertanyaan positif (sangat setuju $=5$, setuju $=4$, ragu-ragu $=3$, tidak setuju $=2$, sangat tidak setuju $=1$ ) dan pertanyaan negatif ( sangat setuju $=1$, setuju $=2$, ragu-ragu $=3$, tidak setuju $=4$, sangat tidak setuju $=5$ ).

Kuisioner pengetahuan terdiri dari 16 pertanyaan mengenai pengetahuan pemeliharaan kesehatan gigi dan mulut, dengan pertanyaan sebagai berikut: 1 . Penyebab gigi berlubang adalah sisa makanan yang tidak dibersihkan; 2. Menyikat gigi menyebabkan gigi berlubang; 3 . Menyikat gigi membuat gigi menjadi lebih putih; 4. Menyikat gigi dua kali sehari ketika mandi pagi dan mandi sore; 5. Bentuk bulu sikat gigi yang tepat dengan bulu halus dan ujung kepala sikat mengecil; 6 . Sikat gigi yang tepat dengan bulu yang keras dan kuat; 7 . Sikat gigi sebaiknya diganti tiap 6 bulan sekali; 8 . Makanan manis dan lengket dapat merusak gigi; 9. Kesehatan gigi dan mulut mempengaruhi kondisi kesehatan secara umum; 10. Sikat gigi sebaiknya diganti tiap 3 bulan sekali; 11. Merokok mempengaruhi kesehatan gigi dan mulut; 12. Gigi ditambal ketika merusak penampilan; 13. Gigi berlubang dapat ditularkan oleh orang lain; 14. Kekurangan vitamin dapat mempengaruhi gusi; 15. Gigi ditambal ketika gigi berlubang dan menimbulkan rasa sakit; 16 . Menggunakan tusuk gigi dapat merusak struktur gigi. Pengukuran pengetahuan dimana setiap jawaban benar diberi skor 3, jawaban salah diberi skor 2, dan jawaban tidak tahu diberi skor 1. Skor masing-masing dijumlahkan dan diberi kriteria: buruk (skor total=1-16), sedang (skor total=17-32), atau baik (skor total=33-48). Paired t-test digunakan untuk mengetahui perbedaan sikap dan pengetahuan sebelum dan sesudah perlakuan pada tiap kelompok penelitian. Penelitian ini telah mendapatkan ethical clearance dari Komite Etik Penelitian Fakultas Kedokteran dan Ilmu Kesehatan Universitas Muhammadiyah Yogyakarta dengan nomor: 011/EC KEPK FKIK UMY/I/2019.

\section{Analisis Statistik}

Analisis data yang digunakan untuk membandingkan perbedaan antara kedua metode pembelajaran terhadap sikap dan pengetahuan kesehatan gigi mulut adalah independent $t$-test.

\section{HASIL}

Penelitian ini melibatkan seluruh siswa kelas V SD Muhammadiyah Suronatan Kota Yogyakarta pada usia 
10-11 tahun berjumlah 68 siswa, kelompok A (metode jigsaw) sejumlah 36 siswa dan kelompok B (metode konvensional) berjumlah 32 siswa. Uji normalitas pada penelitian ini menggunakan uji Saphiro-Wilk karena besar sampel kurang dari 50 orang. Terdapat data uji normalitas sikap dan pengetahuan tentang kesehatan gigi dan mulut pada metode pembelajaran kooperatif jigsaw dan metode pembelajaran konvensional. Nilai probabilitas sikap dan pengetahuan reponden pada metode pembelajaran kooperatif jigsaw dan metode pembelajaran konvensional adalah $\mathrm{p}>0,05$ berarti data tersebut berdistribusi normal, sehingga dapat dilakukan uji Paired t-test.

Hasil data pada Tabel 1 menunjukkan bahwa terdapat perbedaan yang bermakna antara pre-test dan post-test mengenai sikap dan pengetahuan tentang kesehatan gigi dan mulut pada semua metode pembelajaran. Independent sample t-test digunakan untuk mengetahui ada tidaknya perbedaan mean atau rerata yang bermakna antara sikap dan pengetahuan menggunakan metode pembelajaran kooperatif jigsaw dan metode pembelajaran konvensional. Berdasarkan hasil Tabel 2 nilai $\mathrm{p}<0,05$, hal ini menunjukkan bahwa terdapat perbedaan yang siginifikan pada sikap dan pengetahuan tentang kesehatan gigi dan mulut antara metode pembelajaraan kooperatif jigsaw dengan metode konvensional.

Tabel 1. Hasil Uji paired sample T-test antara sebelum perlakuan (pre-test) dan sesudah perlakuan (post-test)

\begin{tabular}{|c|c|c|c|c|}
\hline \multicolumn{2}{|c|}{ Variabel Penelitian } & Mean + SD & $\mathbf{N}$ & $\mathbf{p}$ \\
\hline $\begin{array}{l}\text { Pengetahuan terhadap } \\
\text { kesehatan gigi dan } \\
\text { mulut menggunakan } \\
\text { metode pembelajaran } \\
\text { kooperatif jigsaw }\end{array}$ & $\begin{array}{l}\text { Post } \\
\text { Test }\end{array}$ & $38,61 \pm 4,080$ & 36 & 0,000 \\
\hline $\begin{array}{l}\text { Pengetahuan terhadap } \\
\text { kesehatan gigi dan } \\
\text { mulut menggunakan } \\
\text { metode pembelajaran } \\
\text { konvensional }\end{array}$ & $\begin{array}{l}\text { Pre } \\
\text { Test }\end{array}$ & $38,69 \pm 6,040$ & 32 & 0,015 \\
\hline $\begin{array}{l}\text { Sikap terhadap } \\
\text { kesehatan gigi dan } \\
\text { mulut menggunakan } \\
\text { metode pembelajaran } \\
\text { kooperatif jigsaw }\end{array}$ & $\begin{array}{l}\text { Pre } \\
\text { Test } \\
\text { Post } \\
\text { Test }\end{array}$ & $\begin{array}{l}54,67 \pm 3,971 \\
64,42 \pm 3,184\end{array}$ & 36 & 0,000 \\
\hline $\begin{array}{l}\text { Sikap terhadap } \\
\text { kesehatan gigi dan } \\
\text { mulut menggunakan } \\
\text { metode pembelajaran } \\
\text { konvensional }\end{array}$ & $\begin{array}{l}\text { Pre } \\
\text { Test } \\
\text { Post } \\
\text { Test }\end{array}$ & $50,31 \pm 3,771$ & 32 & 0,000 \\
\hline
\end{tabular}

Tabel 2. Hasil Uji Independent T-test pada aspek pengetahuan dan sikap antara metode jigsaw dengan konvensional

\begin{tabular}{ccccc}
\hline & & N & Mean & p \\
\hline \multirow{3}{*}{ Pengetahuan } & Jigsaw & 36 & 44,25 & \\
& Konvensional & 32 & 41,06 & 0,003 \\
\multirow{2}{*}{ Sikap } & Jigsaw & 36 & 64,42 & \\
& Konvensional & 32 & 56,28 & 0,000 \\
\hline
\end{tabular}

\section{PEMBAHASAN}

Pada analisis data Paired sample t-test didapatkan hasil yaitu sikap dan pengetahuan tentang kesehatan gigi dan mulut pada metode pembelajaran kooperatif tipe jigsaw lebih tinggi dibandingkan dengan metode pembelajaran konvensional. Penelitian ini sejalan dengan penelitian Hasanah (2015), yang menunjukkan bahwa metode pembelajaran koooperatif jigsaw memiliki perbedaan hasil belajar lebih tinggi dibandingkan metode pembelajaran konvensional. Hal ini dapat disebabkan karena metode pembelajaran kooperatif jigsaw lebih aktif, kreatif dan dapat meningkatkan kerjasama antar kelompok dimana proses pembelajaran kooperatif jigsaw dilakukan melalui diskusi oleh kelompok ahli dan kelompok asal. ${ }^{9}$ Metode pembelajaran jigsaw memiliki beberapa keunggulan, seperti dalam penelitian yang dilakukan oleh Rosyidah (2016) yang menyatakan keunggulan tersebut antara lain: siswa menjadi lebih mandiri dan tidak mutlak terikat pada guru, dapat mengemukakan gagasannya secara verbal, dan menguji serta membandingkan dengan gagasan atau opini orang lain dalam satu kelompok maupun dari kelompok lain, selain itu siswa menjadi terlatih untuk bertanggung jawab atas tugas yang diberikan. ${ }^{10}$

Hasil uji independent sample t-test antara metode pembelajaran kooperatif tipe jigsaw dengan metode pembelajaran konvensional menunjukkan hasil bahwa terdapat perbedaan yang bermakna pada sikap dan pengetahuan. Hasil penelitian ini sejalan dengan penelitian yang dilakukan oleh Nisa, dkk (2018) yang menyatakan bahwa metode tipe jigsaw lebih berhasil dibandingkan dengan metode konvensional (ceramah). Metode pembelajaran konvensional menunjukkan peningkatan hasil belajar, namun peningkatan tersebut masih rendah dibandingkan metode pembelajaran kooperatif jigsaw. ${ }^{11}$ Hasil penelitian ini sesuai dengan penelitian oleh Ibrahim (2017), yaitu metode pembelajaran konvensional menunjukkan peningkatan hasil belajar tetapi kurang efektif dibandingkan dengan metode pembelajaran kooperatif jigsaw dikarenakan oleh beberapa faktor antara lain: pengetahuan dan pengalaman 
siswa bergantung pada materi yang disampaikan oleh guru. Interaksi antara guru dengan siswa menjadi tidak terwujud karena guru aktif mentransfer pengetahuan sedangkan siswa hanya menerima pengetahuan, dengan kata lain pembelajaran terpusat pada guru sehingga proses belajar-mengajar bersifat monoton. ${ }^{12}$

Penelitian oleh Rahtyanti dkk (2018), menyatakan bahwa terdapat hubungan yang signifikan antara karies gigi dengan pengetahuan kesehatan gigi dan mulut. Semakin rendah pengetahuan maka semakin tinggi nilai indeks karies gigi. Pengetahuan mempengaruhi sikap atau perilaku dalam kesehatan, khususnya kesehatan gigi dan mulut. Pengetahuan yang baik mempengaruhi sikap atau perilaku terhadap kesehatan gigi dan mulut, sebaliknya kurangnya pengetahuan mengenai pemeliharaan akan mengakibatkan timbulnya sikap mengabaikan kebersihan dan kesehatan gigi dan mulut. ${ }^{13}$ Hal ini sesuai juga dengan penelitian yang dilakukan oleh Arifah (2016), bahwa terdapat hubungan yang bermakna antara pengetahuan, sikap dan tindakan pemeliharaan kesehatan gigi dan mulut terhadap status karies, semakin tinggi nilai pengetahuan, sikap, dan tindakan pemeliharaan kesehatan gigi dan mulut maka nilai indeks karies akan semakin rendah. ${ }^{1}$ Salah satu faktor penentu keberhasilan pada penelitian ini juga dipengaruhi oleh usia responden. Pada penelitian ini peneliti menggunakan subyek anak dengan rata-rata usia 10-11 tahun. Teori Piaget menyatakan bahwa anak usia 10-11 tahun tersebut masuk pada tahap operasional konkrit. Pada penelitian Ibda (2015), menyatakan bahwa pada tahap operasional konkrit anak sudah cukup matang untuk menggunakan pemikiran logika atau operasi, tetapi hanya untuk objek fisik, atau dengan kata lain anak sudah dapat memahami isi atau konten materi yang diberikan. ${ }^{14}$

\section{KONFLIK KEPENTINGAN}

Penulis menyatakan tidak terdapat konflik kepentingan pada penulisan artikel ini

\section{DAFTAR PUSTAKA}

1. Arifah AN. Hubungan pengetahuan, sikap dan tindakan kesehatan gigi dan mulut terhadap status kebersihan mulut pelajar SMP/Mts Pondok Pesantren Putri Ummul Mukminin. [Skripsi]. Makassar: FKG UNHAS. 2016.

2. Mahardika AR, Susilarti, Marjana. Tingkat pengetahuan kesehatan gigi dan mulut dengan perilaku menggosok gigi pada siswa kelas IV dan V. Jurnal Gigi dan Mulut. 2016;03(01):73-78.

3. Nurlila RU, Fua JL, Meliana. Pengaruh pendidikan kesehatan terhadap pengetahuan tentang kesehatan gigi pada siswa di SD Kartika XX-10 Kota Kendari tahun 2015. Jurnal Al-Ta'dib. 2018;9(1):94-119.

4. Suratri MA, Sintawati F, Andayasari I. Pengetahuan, sikap, dan perilaku orang tua tentang kesehatan gigi dan mulut pada anak usia taman kanak-kanak di Provinsi Daerah Istimewa Yogyakarta dan Provinsi Banten tahun 2014. Media Litbangkes. 2016;26(2):199-126.

5. Azwar S. Sikap Manusia teori dan pengukurannya. Jakarta: Pustaka Pelajar. 2016.

6. Hestieyonini H, Kiswaluyo, Widi R, Meilawaty Z. Perilaku menjaga kesehatan gigi dan mulut pada santri Pondok Pesantren Al-Azhar Jember. Stomatognatic J. K. G Unej. 2013;10(1):17-20.

7. Suprihatiningrum J. Strategi pembelajaran : teori dan aplikasi. Yogyakarta: Ar - Ruzz Media; 2014.

8. Hasanah U. Pengaruh model pembelajaran kooperatif tipe jigsaw terhadap motivasi belajar siswa. Pedagogy. 2015;03(01):45-48.

9. Trianingsih R. Pengantar praktik mendidik anak usia sekolah dasar. Journal Al Ibtida. 2016;3(2):197-211.

10. Rosyidah. Pengaruh model pembelajaran kooperatif tipe jigsaw terhadap hasil belajar matematika siswa kelas VIII SMP Negeri 6 Metro. Jurnal Susunan Artikel Pendidikan. 2016;1(2):115-124.

11. Nisa K, Thamrin AG, Agustin RS. perbandingan model pembelajaran kooperatif tipe jigsaw dengan model konvensional terhadap hasil belajar siswa pada mata pelajaran ilmu bahan bangunan kelas $\mathrm{X}$ teknik gambar bangunan SMK Negeri 4 Sukoharjo. Indonesian Journal of Civil Enginering Education. 2018;4(1):67-78.

12. Ibrahim. perpaduan model pembelajaran aktif konvensional (ceramah) dengan cooperatif (make-a match) untuk meningkatkan hasil belajar pendidikan kewarganegaraan. Suara Guru: Jurnal Ilmu Pendidikan Sosial, sains, dan Humaniora. 2017;3(2):199-211.

13. Rahtyanti GCS, Hadnyanawati H, Wulandari E. Hubungan pengetahuan kesehatan gigi dan mulut dengan karies gigi pada mahasiswa baru Fakultas Kedokteran Gigi Universitas Jember tahun akademik 2016/2017. E-Jurnal Pustaka Kesehatan. 2018;6(1): 167-171.

14. Ibda F. Perkembangan kognitif: teori Jean Piaget. Jurnal Intelektualita. 2015;3(1):27-38. 